\title{
経済改革後中国農業の成長と波動の経済分析
}

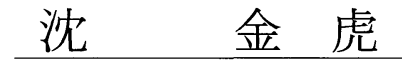

\section{An Analysis of Growth and Fluctuations in Chinese Agriculture after the Economic Reforms}

\author{
Shen Jin-hu (Kyoto University)
}

To analyze the mechanisms of growth and fluctuations in Chinese agricultural production after the Economic Reforms, we surveyed the process of rural economic reforms and the changes in the agricultural environment since 1978, then estimated the stochastic frontier production function of farming sector using the panel data from 28 provinces for 1980-1995. Based on these results, we also made a growth accounting analysis. The following findings appeared:

1. In the whole period covered by our research, the growth in farming production was supported mainly by modern inputs such as chemical fertilizers and farm machinery, but the fluctuations were dependent on the efficiency in production process. 2. For 1980-1984, Chinese farming production grew rapidly. About $52 \%$ of this growth came from the increase in inputs, $42 \%$ was due to the improvements in production efficiency brought about by introduction of the responsibility system. 3. However, the growth of farming production soon slowed down after 1985. Little part of this slowdown was attributed to inputs and climate conditions, while the majority was due to the fact that the contributions made by the responsibility system ceased, trade terms took a turn for the worse. 4. Starting in 1990, we noticed a slight increase in the growth of farming sector. The reason for this improvement was mainly due to the improvement of trade terms and the increase in government expenditures on agriculture.

\section{1. はじめに}

1970年代末以降，経済改革を実施した中国の農業は 一時目覚ましい成長を見せていたが，80年代後半以 降, 都市経済システムや農産物の流通・価格制度の改 革が始まるにつれ, 穀物, 綿花などに代表される耕種 農業は急速に低迷し始めた ${ }^{1)}$.

人口が多く, 開発途上にある中国にとって, 農業生 産低迷の問題は重大である. 近年, 穀物輸入増大など の原因で中国の食料問題に対する国際的な関心が高ま っているが，国際市場への影響は別にして，国内に特 いてもェンゲル係数が未だ $50 \%$ 前後の水準にあり, 耕 種農業, 特に食料生産の低迷は国民生活や経済全体に 影響を及んでいる，中国政府はこの問題の重要性を認 識し，80年代末頃から農業予算を増やすなど, 農業生 産の振興を図ってきた。これらの政策を評価し, 将来 の農政を展開するためには，いままでの農業生産の構 造と農業成長を左右する要因の解明が求められてい
る・

経済改革以降，80年代半ば前後までの中国農業の成 長について, 既に多くの研究がなされている22. しか し, 生産振興の立場から85年以降の生産停滞の原因, 並びに生産責任制以外の政策効果を解明することがよ り重要であり, それについて, 論議されてはいるもの の, 論理的かつ実証的な研究は少ないのが現状であ る.

そのため，本稿では農業組織と環境条件の目まぐる しい変化に着目し，いわゆるフロンティア生産関数と 技術非効率関数（技術非効率とその影響要因との回帰 関数)を計測することにより，80年代以降中国農業(耕 種農業）生産の成長，停滞の原因を，要素投入，技術 進歩拉よび効率変化といら 3 つの側面から計量的に解 明する.

以下， 2 節ではまず農業生産変化の背景を解明する ため，78年以降中国農村経済改革の過程と農業経済環 境の変化を概観する． 3 節と 4 節では1980～95年の間 
にわたる省市自治区別データを用いて耕種農業のフロ ンティア生産関数と技術非効率関数を計測し，5節で はその結果に基づき，成長会計分析を行う。

\section{2. 中国農村経済改革の過程と農業経済環境の 変化}

\section{1）農村経済改革の過程}

周知のよ5に, 中国の農村改革は78年から始まっ た. 以来二十年間に，84年まではミク口的な生産組 織，それ以降はマク口的な価格制度などを中心に改革 が進められてきた。

84年までの期間についてみると，主に二つの側面で 改革が行われた。一つは農産物の政府買付価格の引き 上げで，いま一つは生産責任制の導入である．前者は 79年に行われ，これまで25年間据古置かれていた農産 物の買付価格は，平均買付けで $22 \%$ ，超過買付けで40 \%と大幅に引き上げられた（表 1 ）。一方，後者は最 初に一部の貧困地域に試行されていたが，中央政府の 承認を得て，1980～84年の間に破竹の勢いで全国に普 及した3)。その延長線上に扣いて，84年には行政改革 の一環として人民公社が解散され，これをもって末端 の農業生産組織の改革はほぼ完了した。

85年から，中国政府は一方では国民経済の根幹とな る都市経済の改革に着手し，他方では本格的な農産物
・農用資材の流通・価格制度の改革を実施し始めた. 農産物に関しては，85年頃からまず生鮮農産物の市 場を開放し，価格を自由化した。また穀物，綿花に対 して, 従来強制的な「計画買付制度」に代わって，新 たに「契約買付制度」が実施された。しかし，都市部 での食糧等の配給制が続けられたため，「契約買付」 は実質上は強制的に行われ，買付価格も低く抑えられ ていた．90年代に入り，政府はようやく食糧配給制度 の改革に着手した．91年，92年に配給価格の大幅な引 き上げを実施し，翌93年にこれまで40年間に渡って続 けられてきた都市住民への食糧配給制度を廃止した。 それ以降，穀物の政府買付量は大幅に縮小し，買付価 格も需給関係をみて決めるようになった.

一方，農産物の計画買付とセットになっていた農用 資材の流通・価格制度も改革の対象とされた. 79年に 農産物買付価格が大幅に引き上げられた時，農用資材 の価格は修正されなかったが，85年から従来の低価 格, 計画供給のルート以外に自由な市場流通ルートが 新設され, いわゆる「2本レール制度」がスタートし た.ところが，中国に拈いて化学肥料などの農用資材 は著しい供給不足の状況にあり，「2本レール制度」 は価格高騰と市場混乱を引き起こし，大きな問題とな った．1987年から穀物等の「契約買付」計画達成の手 段として，化学肥料などは農産物の買付量とリンクし

表 1 . 経済改革後農産物，農用資材の価格指数の変化（1985年＝100）

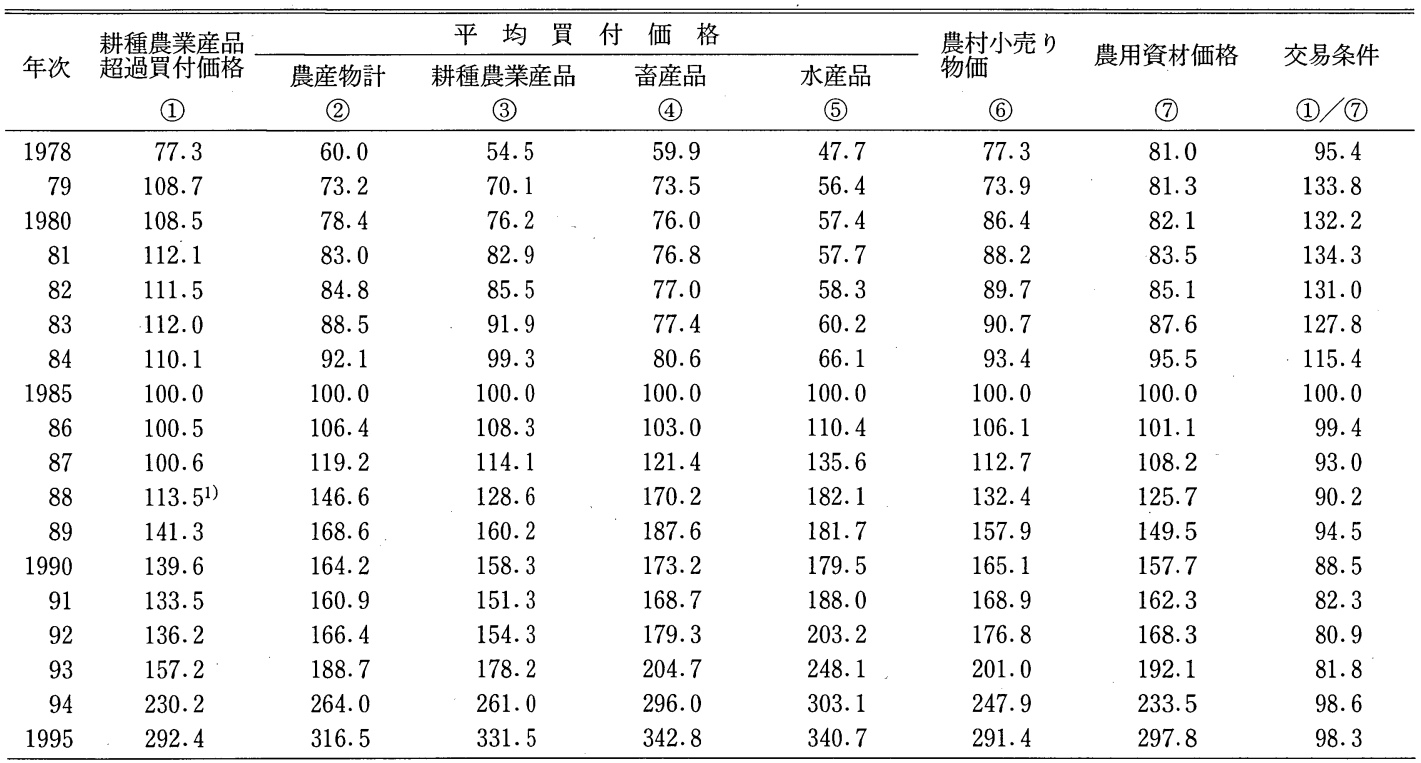

資料：(1)は文献〔11〕の p. 81，他は国家統計局『中国統計年鑑』各年版による.

註 : 1）88年以降の超過買付価格指数は平均買付価格の対前年比をかけて計算した. 
て割安な価格で農家に供給されるようになったもの の, 市場流通の割合の増大と公定価格の頻繁な引上げ により, 農用資材の価格は年々上昇し続けてきた（表 $1)$.

従って，農産物買付価格と農用資材販売価格との相 対的変化に関して，1984年までとそれ以降の状況は大 きく異なった。耕種農産物の超過買付価格指数と農用 資材価格指数との比 $(85$ 年 $=100$, 以下交易条件と呼

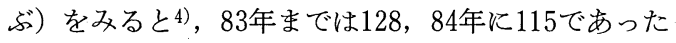
が，それ以降は年々低下し，92年には 80 まで下がっ た. 近年, 農産物買付価格の上昇で, 交易条件は改善 の方向に向かったが，まだ85年の水準にまでは回復し ていない。

\section{2 ）他の農村経済環境の変化}

一方, 農業生産を取り巻く他の経済環境も著しく変 化してきた，その一つは，郷鎮企業の急速な発展と農 村産業構造の変貌である. 特に 85 年以降, 農村企業の 重要性が再認識され, 国家経済政策に打いても税制, 融資面の優遇策が取られたことなどにより, 農村非農 業の発展は一層加速した。 その結果, 1984年に農村社 会総生産額（原語では農村社会総産値）の $36.8 \%$ 占 めていた非農業の比率は 90 年に $53.9 \% ， 94$ 年現在は $74.3 \%$ でに上昇した5).

いま一つは, 人民公社の解散に伴ら農業に対する社 会サービス機能の低下である. その典型は農業技術普
及である，経済改革以前まで，中国の農業技術普及は 県, 人民公社, 生産大隊, 生産隊を結ぶ四段階科学実 験網が整い，技術者の賃金と運営費も政府と集団によ って保証されていた．生産責任制の普及に伴い，末端 普及組織の貢金と運営費も次第に請負制に切り替兄ら れ，人民公社解散後請負制は一層強化された．技術者 の報酬基盤が不安定となり, 運営経費も不足のため, 転職者が相次ぎ，技術者の不足と質の低下の問題が表 面化し，農業技術普及所の数さ光1983年から減少し始 めた6).のみならず，零細な家族経営に適しない機械 耕作，灌溉，防除，農用資材の共同購入などに関して も，もともと人民公社がサービスを提供していたが， 人民公社の解散に伴って，旧来のサービス組織の解散 ・機能低下が余儀なくされ，農家へのサービス提供は 年々減少していた7).

80 年代末頃になると, 穀物生産低迷の問題が表面化 した，生産振興を図るため, 政府は農業予算を增や し，また技術普及や他の社会的な援農サービスシステ 么の確立・強化を目指す一連の農業振興政策を取り始 めた ${ }^{8)}$. これらの振興政策により, 予算増加の外, 農 業への地方政府の関心が強まったことの効果がもたら され，87年からは技術普及所の数は回復に向かい，農 業への各種社会サービス提供もこの時期から増え始め た.

以上, 70 年代末以降, 中国農村の経済改革過程とそ

表 2 . 耕種農業の産出と投入の変化（1980～95年）

\begin{tabular}{|c|c|c|c|c|c|c|c|c|c|}
\hline 年次 & $\begin{array}{l}\text { 実質総生産 } \\
\text { 額) }\end{array}$ & 耕地面積 & 作付面積 & 就業労働力 ${ }^{2)}$ & 農業機械馬力 & 役畜頭数 & $\begin{array}{l}\text { 化学肥料 } \\
\text { 施用量 }\end{array}$ & $\begin{array}{l}\text { 実質農業財政 } \\
\text { 支数3 }\end{array}$ & 被㷋率 \\
\hline & 億元 & 万 ha & 万 ha & 万人 & 万皌 & 万頭 & 万t & $\%$ & $\%$ \\
\hline 1980 & 1342 & 9908 & 14616 & 21495 & 14717 & 4971 & 1272 & 108.6 & 15.3 \\
\hline 81 & 1487 & 9881 & 14494 & 22283 & 15949 & 5356 & 1335 & 87.1 & 12.9 \\
\hline 82 & 1648 & 9838 & 14447 & 21920 & 16586 & 5718 & 1513 & 87.0 & 11.1 \\
\hline 83 & 1788 & 9813 & 14378 & 22173 & 17998 & 6019 & 1659 & 96.1 & 11.3 \\
\hline 84 & 1960 & 9763 & 14401 & 21502 & 19467 & 6281 & 1739 & 100.2 & 10.6 \\
\hline 1985 & 1926 & 9665 & 14342 & 20353 & 20882 & 6555 & 1775 & 100.0 & 15.8 \\
\hline 86 & 1943 & 9601 & 14400 & 19943 & 22912 & 6809 & 1930 & 114.4 & 16.4 \\
\hline 87 & 2046 & 9567 & 14475 & 20052 & 24797 & 7007 & 1997 & 114.3 & 14.1 \\
\hline 88 & 2043 & 9550 & 14469 & 19755 & 26534 & 7052 & 2140 & 107.8 & 16.5 \\
\hline 89 & 2079 & 9544 & 14634 & 20237 & 28005 & 7310 & 2356 & 112.6 & 16.7 \\
\hline 1990 & 2259 & 9545 & 14815 & 20838 & 28689 & 7480 & 2589 & 125.5 & 12.0 \\
\hline 91 & 2276 & 9543 & 14937 & 21208 & 29370 & 7570 & 2803 & 135.5 & 18.6 \\
\hline 92 & 2353 & 9521 & 14879 & 20656 & 30288 & 7613 & 2928 & 143.5 & 17.4 \\
\hline 93 & 2490 & 9488 & 14760 & 19899 & 31505 & 7916 & 3151 & 149.0 & 15.6 \\
\hline 94 & 2549 & 9468 & 14803 & 18839 & 33766 & 8338 & 3317 & 146.1 & 21.2 \\
\hline 1995 & 2734 & 9475 & 14966 & 17991 & 36059 & 8688 & 3592 & 161.1 & 22.0 \\
\hline
\end{tabular}

資料：前掲『中国農業年鑑』『中国農村統計年鑑』各年版による.

註 : 1) 実質総生産額は1980年不変価格表示のものである.

2）耕種業の就業労働者数は生産額構成比から推定された. 本文註 13 参照.

3）実質農業財政支出指数は農村小売り物価指数（1985年＝100）で実質化した. 
れに伴う農業生産環境の変化を見てきた，表 2 には激 しい環境変化の中, 中国農業が紆余曲折しながら全体 的に発展してきた過程がまとめられている.

\section{3. 分析方法}

\section{1）フロンティア生産関数}

農業成長の源泉, そして成長の速度を左右した原因 は何処にあるのか. 本節では, フロンティア生産関数 の研究を行らとして, この解明を試みる。

ミクロ経済学の生産理論では, 企業が最も効率的な 状態で生産を行らことを前提に，要素投入と生産量と の対応関係を生産関数の形で表し, また生産量の変化 を要素投入の変化と生産関数のシフト（技術進歩）の 二つの要因で説明している. しかし, 現実には農業を 含め, 企業の生産が生産関数フロンティア上の最も効 率的な状態下で行われるのは希であり，その内側の非 効率な状態下で行われているのが普通である．そのた め, 効率の変化も生産変動の要因の一つとして考兄る 必要がある. 前節でみた制度・環境変化の激しい中国 農業の場合には，特にこのことが妥当する.

生産効率とその変化を明示的に取り扱学るのは, フ ロンティア関数のアプローチである. そのアプローチ は1957年に Farrel が最初に提唱したが，後に多くの 研究者によって研鑽を重ねられ，様々なフロンティア 関数, 生産効率の計測方法が開発された.

主要な方法として, プログラミング法 (Programming Approach), 修正プログラミング法 (Modified Programming Approach), 非確率統計フロンティア 法 (Deterministic Statistical Frontier Approach), 確 率フロンティア法 (Stochastic Frontier Approach), $4 つ か ゙ あ る{ }^{9}$. それらのうち, 両プログラミング法と 非確率統計フロンティア法は「所与投入に対する技術 的に最大可能生産量」といらフロンティア生産関数の 定義に忠実である反面, 生産過程やデータ観測中に発 生しらるノイズによる変動や誤差を認めない。このた め, もし観測データに異常值が存在すれば, フロンテ ィア関数, 生産効率の計測結果がそれに敏感に反応 し, バイアスが生じるという問題がある (Pitt \& Lee, 1981; Lovell \& Schmidt, 1988). それを回避するため, 本稿以下では確率フロンティア法を使用する.

いま，次のようなフロンティア生産関数を考兄よ $\zeta^{10)}$.

$$
\ln \mathrm{Y}_{\mathrm{it}}=\operatorname{lnf}\left(\mathrm{X}_{\mathrm{it}}\right)+\mathrm{V}_{\mathrm{it}}-\mathrm{U}_{\mathrm{it}}
$$

ただし, 添字 $\mathrm{i}$ は地域番号, $\mathrm{t}$ は年次, $\mathrm{Y}_{\mathrm{it}}$ は生産 額11)， $\mathrm{X}_{\mathrm{it}}$ は投入される生産要素のベクトル， $\mathrm{f}\left(\mathrm{X}_{\mathrm{it}}\right)$
はフロンティア関数，つまり要素 $\mathrm{X}_{\mathrm{it}}$ が投入された時 の最大生産量を表す． $\mathrm{V}_{\mathrm{it}}$ と $\mathrm{U}_{\mathrm{it}}$ は確率変数であるが，

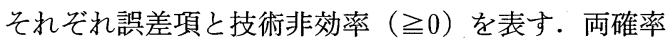
変数について, $\mathrm{V}_{\text {it }}$ は $\mathrm{N}\left(0, \sigma_{\mathrm{v}}^{2}\right), \mathrm{U}_{\mathrm{it}}$ は $(0$ 点で $)$ 先 端が切られた $\mathrm{N}\left(Z_{\mathrm{it}} \delta, \sigma_{\mathrm{u}}{ }^{2}\right)$ 飞従い，相互間は独立 $\left(\mathrm{t} \neq \mathrm{t}^{\prime}, \mathrm{i} \neq \mathrm{j}\right.$ の時, $\left.\mathrm{E}\left(\mathrm{V}_{\mathrm{it}}, \mathrm{U}_{\mathrm{it}}{ }^{\prime}\right)=\mathrm{E}\left(\mathrm{V}_{\mathrm{it}}, \mathrm{U}_{\mathrm{jt}}\right)=0\right)$ で あるとする。な拉，

$$
\mathrm{U}_{\mathrm{it}}=Z_{\mathrm{it}} \delta+\mathrm{w}_{\mathrm{it}}
$$

$Z_{\text {it }}$ は技術非効率の影響要素, $\delta$ はそのバラメータの ベクトルで， $\mathrm{w}_{\mathrm{it}}$ は誤差項である.

そこで， $\mathrm{t}$ 時， $\mathrm{i}$ 農家や地域の通常の意味での生産 効率は， $\mathrm{Y}_{\mathrm{it}} / \mathrm{f}\left(\mathrm{X}_{\mathrm{it}}\right) \mathrm{e}^{\mathrm{Vit}}$ と定義できるが，それは，つま り, $\mathrm{e}^{-\mathrm{Uit}}=\exp \left(-Z_{\mathrm{it}} \delta-\mathrm{w}_{\mathrm{it}}\right)$ である. $\varepsilon_{\mathrm{it}}=\mathrm{V}_{\mathrm{it}}-\mathrm{U}_{\mathrm{it}}$ が 与兄られた時の $\mathrm{U}_{\mathrm{it}}$ の条件分布に基づいて，その計算 は次の式で行党る12).

$$
\mathrm{E}\left\{\mathrm{e}^{-\mathrm{Uit}} \mid \varepsilon_{\mathrm{it}}\right\}=\left\{\exp \left(-\mu_{\mathrm{it}}^{*}+\frac{1}{2} \sigma_{*}^{2}\right)\right\}\left\{\frac{\mathrm{F}\left(\mu_{\mathrm{it}}^{*} / \sigma_{*}-\sigma_{*}\right)}{\mathrm{F}\left(\mu_{\mathrm{it}}^{*} / \sigma_{*}\right)}\right\}
$$

ただし， $\mu_{\mathrm{it}}^{*}=\left(\sigma_{\mathrm{v}}{ }^{2} Z_{\mathrm{it}} \delta-\sigma_{\mathrm{u}}{ }^{2} \varepsilon_{\mathrm{it}}\right) /\left(\sigma_{\mathrm{v}}{ }^{2}+\sigma_{\mathrm{u}}{ }^{2}\right), \quad \sigma_{*}^{2}=\sigma_{\mathrm{v}}{ }^{2} \sigma_{\mathrm{u}}{ }^{2} /$ $\left(\sigma_{\mathrm{v}}{ }^{2}+\sigma_{\mathrm{u}}{ }^{2}\right)$, そして, $\mathrm{F}(\cdot)$ は $($ ）内の標準正規変 数の分布関数である.

\section{2 ) 関数の特定と計測データ}

次に，関数式と説明変数を特定しなければならな い. 関数式 $\mathrm{f}\left(\mathrm{X}_{\mathrm{it}}\right)$ について, CD 型, CES 型とトラ ンスログ型はよく使われる，そのらち，トランスログ 型は最もフレキシブルであるが，説明変数が多くで多 重共線関係になりやすい，また CES 型は代替弾力性 1 の前提を要しない点で $\mathrm{CD}$ 型より柔軟性があるも のの, 非線形関数なので, 推定が難しい，それらに比 べて， CD 型生産関数は簡単ではあるが，推定係数が 生産弾力性であり, 生産弾力性の和が規模弾力性とな るなど，多くの興味ある性質を備えている．農業分野 ではその有効性が特に発揮できると言われ，中国農業 に関する既存研究（文献〔11]など）も同様のことを 表明したので，本稿ではその CD 型を採用する.

また, 農業生産要素 $(\mathrm{X})$ として, 次のような変数を 取り入れる. (1)延べ作付面積 (S) : ha, (2)労働就業者 数 $(\mathrm{L})$ : ${ }^{13)}$, (3)農業機械之役畜の換算馬力数（以 下，機械・役畜之呼ぶ）(K)：馬力14)，(4)化学肥料使 用量 $(\mathrm{F}): \mathrm{kg}^{15)}$, (5)時間変数 $(\mathrm{T})$, (6)実質農業財政支 出指数 ( $\mathrm{FE}): \%{ }^{16)}$, (7)被災率 (NDP) : \% ${ }^{17)}$ 。最初の 4 つは通常生産要素, 後の 3 つは技術進歩など他の影 響要素である.

そして，技術非効率の影響要因 $(Z)$ として，变則的 な時間变数 $\mathrm{HRS}_{\mathrm{t}}(=0,1,2,3,4, \cdots, 4)$ と耕種 
農産物の超過買付価格指数と農用資材価格指数との比 $\mathrm{AIP}_{\mathrm{t}-1}$ （85年=100）の二つを導入する18)．前者は農 業生産組織19), 後者は農業交易条件の変化を表す。

これらの変数を使って，(1）式と（2）式を具体化 すると，次のように表される。

$$
\begin{gathered}
\ln \mathrm{Y}_{\mathrm{it}}=\mathrm{b}_{0}+\mathrm{b}_{1} \ln \mathrm{S}_{\mathrm{it}}+\mathrm{b}_{2} \ln \mathrm{L}_{\mathrm{it}}+\mathrm{b}_{3} \ln \mathrm{K}_{\mathrm{it}}+\mathrm{b}_{4} \ln \mathrm{F}_{\mathrm{it}}+ \\
\mathrm{b}_{5} \mathrm{FE}_{\mathrm{t}}+\mathrm{b}_{6} \mathrm{NDP}_{\mathrm{it}}+\mathrm{b}_{7} \mathrm{~T}_{\mathrm{t}}+\mathrm{V}_{\mathrm{it}}-\mathrm{U}_{\mathrm{it}} \\
\mathrm{U}_{\mathrm{it}}=\delta_{0}+\delta_{1} \mathrm{HRS}_{\mathrm{t}}+\delta_{2} \mathrm{AIP}_{\mathrm{t}-1}+\mathrm{w}_{\mathrm{it}}
\end{gathered}
$$

計測データは，1980～95年の間に渡る省・市・自治 区別横断面データを用いる20). 但し, 農業生産の基礎 単位は農家であるので, Y, S, L, K, F など省市自治 区レベルの総量データは農家数で基準化して推定に用 いた. サンプル数は合計 $448 （=28$ 地域 $\times 16$ 年）であ る.

\section{4. 計測結果}

（4）（5）式のパラメータの最尤推定量は, Coelli
が開発した専用ソフト FRONTIER Ver 4.1 を使古 ば，簡単に得られる21). 表 3 はその結果を示す. 参考 のため, OLS 法で推定した CD 型の平均生産関数の 結果も合わせて掲載した。

フロンティア生産関数に関して, 二つのモデルが推 定されている，そのらち，III モデルは（4)，（5）式を そのまま推定したものである. 時間変数 Tの推定係数 $\left(b_{7}\right)$ をみると, 值が小さく, ゼロとの有意差も認め られないので, 分析期間中に中立的な技術進歩が顕著 でなかったと推測される22). 他の係数推定值について も, 負の労働生産弾力性 $\left(\mathrm{b}_{2}\right)$ が注目される. 中国農 業賦存条件の基本的な特徵は「人が多く土地が少ない こと」であり, 農業労働力が過㮃就業状態にあること はよく指摘されている. 労働生産弾力性の絶対值が小 さいことは, 過剰就業状態と一致するけれども, 負の 生産弾力性は理論的な期待に反し, 常識的にも考光ら

\begin{tabular}{|c|c|c|c|c|c|}
\hline \multirow{2}{*}{ 変 数 } & \multirow{2}{*}{ 推定係数 } & \multicolumn{2}{|c|}{ Average } & \multicolumn{2}{|c|}{ Frontier } \\
\hline & & $\mathrm{I}$ & II & III & $\mathrm{N}$ \\
\hline 常数項 & $\mathrm{b}_{0}$ & $\begin{array}{c}4.858^{* * *} \\
(25.48)\end{array}$ & $\begin{array}{c}4.699^{* * *} \\
(31.42)\end{array}$ & $\begin{array}{c}4.925^{* * * *} \\
(16.04)\end{array}$ & $\begin{array}{c}4.887^{* * *} \\
(28.72)\end{array}$ \\
\hline $\ln S$ & $\mathrm{~b}_{1}$ & $\begin{array}{c}0.474^{* * * *} \\
4.18)\end{array}$ & $\left(\begin{array}{c}0.418^{* * *} \\
3.97)\end{array}\right.$ & $\begin{array}{c}0.502^{* * * *} \\
(20.73)\end{array}$ & $\begin{array}{c}0.404^{* * *} \\
20.05)\end{array}$ \\
\hline $\ln \mathrm{L}$ & $\mathrm{b}_{2}$ & $\begin{array}{c}-0.061^{* *} \\
(-1.74)\end{array}$ & $\begin{array}{c}-0.066^{* *} \\
(-1.92)\end{array}$ & $\begin{array}{c}-0.152^{* * *} \\
(-6.52)\end{array}$ & 0.000 \\
\hline $\ln \mathrm{K}$ & $\mathrm{b}_{3}$ & $\begin{array}{c}0.094^{* *} \\
2.10)\end{array}$ & $\left(^{0.111^{* * * *}} 2.59\right)$ & $\begin{array}{c}0.112^{* * *} \\
5.99)\end{array}$ & $\begin{array}{c}0.187^{* * *} \\
(11.29)\end{array}$ \\
\hline $\ln F$ & $\mathrm{~b}_{4}$ & $\begin{array}{c}0.394^{* * *} \\
(12.94)\end{array}$ & $\begin{array}{c}0.413^{* * *} \\
(15.20)\end{array}$ & $\begin{array}{c}0.492^{* * *} \\
(24.22)\end{array}$ & $\begin{array}{c}0.498^{* * *} \\
(24.27)\end{array}$ \\
\hline $\mathrm{FE}$ & $\mathrm{b}_{5}$ & 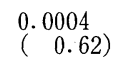 & $\begin{array}{r}0.0009^{* *} \\
(2.18)\end{array}$ & $\begin{array}{l}0.0003 \\
\left(\begin{array}{c}0.27) \\
)\end{array}\right.\end{array}$ & $\begin{array}{c}0.0008^{*} \\
1.37)\end{array}$ \\
\hline NDP & $\mathrm{b}_{6}$ & $\begin{array}{c}-0.441^{* * *} \\
(-9.32)\end{array}$ & $\begin{array}{c}-0.436^{* * * *} \\
(-9.23)\end{array}$ & $\begin{array}{c}-0.588^{* * *} \\
(-8.39)\end{array}$ & $\begin{array}{c}-0.632^{* * *} \\
(-9.14)\end{array}$ \\
\hline $\mathrm{T}$ & $\mathrm{b}_{7}$ & 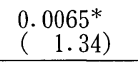 & & $\begin{array}{l}0.0009 \\
\left(\begin{array}{c}0.12 \\
0\end{array}\right)\end{array}$ & \\
\hline 常数項 & $\delta_{0}$ & & & $\begin{array}{c}0.576^{* *} \\
2.26)\end{array}$ & $\begin{array}{c}0.733^{* * *} \\
(5.47)\end{array}$ \\
\hline HRS & $\delta_{1}$ & $\begin{array}{c}0.042^{* * * *} \\
7.14)\end{array}$ & $\begin{array}{c}0.045^{* * *} \\
8.34)\end{array}$ & $\begin{array}{c}-0.040^{* * *} \\
(-3.58)\end{array}$ & $\begin{array}{c}-0.042^{* * * *} \\
(-3.95)\end{array}$ \\
\hline AIP & $\delta_{2}$ & $\begin{array}{c}0.0022^{* * * *} \\
4.72)\end{array}$ & $\begin{array}{c}0.0020^{* * * *} \\
(4.52)\end{array}$ & $\begin{array}{r}-0.0024^{* *} \\
(-2.17)\end{array}$ & $\begin{array}{c}-0.0028^{* * * *} \\
(-2.77)\end{array}$ \\
\hline \multicolumn{2}{|c|}{$\sigma^{2}$} & & & $\begin{array}{c}0.017^{* * *} \\
(13.91)\end{array}$ & $\begin{array}{c}0.020^{* * *} \\
(10.23)\end{array}$ \\
\hline \multicolumn{2}{|c|}{$\lambda$} & & & $\left(\begin{array}{c}0.229 \\
0.40)\end{array}\right.$ & $\begin{array}{c}0.809^{* * *} \\
2.51)\end{array}$ \\
\hline \multicolumn{2}{|c|}{$\mathrm{R}^{2}$} & 0.953 & 0.953 & & \\
\hline \multicolumn{2}{|c|}{ log likelihood } & & & 276.6 & 256.5 \\
\hline \multicolumn{2}{|c|}{$\mathrm{N}$} & 448 & 448 & 448 & 448 \\
\hline
\end{tabular}
れにくい23). そのため, $\mathrm{N}$ モデルでは強制的に $\mathrm{b}_{2}=$

表 3 . 中国耕種農業の生産関数の推定結果

資料：篚者作成.

註 : 1) I , II の推定は $\ln \mathrm{Y}_{\mathrm{it}}=\mathrm{b}_{0}+\mathrm{b}_{1} \ln \mathrm{S}_{\mathrm{it}}+\mathrm{b}_{2} \ln \mathrm{L}_{\mathrm{it}}+\mathrm{b}_{3} \operatorname{lnK}_{\mathrm{it}}+\mathrm{b}_{4} \ln \mathrm{F}_{\mathrm{it}}+\mathrm{b}_{5} \mathrm{FE}_{\mathrm{t}}+\mathrm{b}_{6} \mathrm{NDP}_{\mathrm{it}}+\mathrm{b}_{7} \mathrm{~T}_{\mathrm{t}}+\delta_{1} \mathrm{HRS}_{\mathrm{t}}+\delta_{2} \mathrm{AIP}_{\mathrm{t}-1}+\Sigma \mathrm{c}_{\mathrm{j}} \mathrm{D}_{\mathrm{j}}+\nu_{\mathrm{it}}$ で行った. $D_{j}(j=2,3, \cdots, 28)$ は地域ダミーである. $c_{j}$ の表示は省略.

2) $\sigma^{2}=\sigma_{\mathrm{V}}+{ }^{2} \sigma_{\mathrm{U}}^{2}, \lambda=\sigma_{\mathrm{U}}^{2} / \sigma^{2}$.

3）（）内の数字は $\mathrm{t}$ 值で, ***は $1 \%$ ，**は $5 \%$ ，*は10\%で有意であることを示す. 
$\mathrm{b}_{7}=0$ とし, 残る説明変数でフロンティア生産関数な ぞを推定した．NIの結果を正と比較すると，生産弾力 性などの推定值は若干変化したものの, 汪とんど係数 の $\mathrm{t}$ 值が増大し, 特に $\mathrm{b}_{5}$ と $\lambda$ の有意性は大きく改善 された. $\lambda\left(=\sigma_{\mathrm{U}}^{2} / \sigma^{2}\right)$ が 1 に近い, ゼロとの有意差が 認められたのは, 農業生産の変動に技術非効率の影響 が大きいことを意味している．次節での成長分析は $\mathbb{N}$ モデルの結果を使用する．とりあ劣ず，そのモデルの 推定生産弾力性などをみよう。

まず, フロンティア生産関数について, 通常の生産 要素の生産弾力性は土地が 0.40 , 機械・役畜が 0.19 , 化学肥料が 0.50 と推定された. 土地, 化学肥料の弾力 性は高く, 機械・役畜のそれは低いのが特徵である が, これは上記賦存条件の外, 経営規模の零細性と戋 場分散など中国農業の現状を反映していると思われ る. その外, 農業財政支出指数 (FE) に正の係数が推 定され，10\%の水準で有意差が認められた. 言うまで もなく, これは他の条件が同じ状況で農業財政支出が 農業総生産額の成長に効果があることを意味する。ま た, 被災率 (NDP) には負の係数が得られた. 係数が 負であることは経験的な常識と一致する。 -0.63 とい ら值も被㷋率が $1 \%$ 高くなれば, 耕種農業の生産額が $0.63 \%$ 減ることを意味している.

一方，技術非効率関数の推定係数をみると，三つと も符号条件が理論的な期待と一致し，ゼ口との有意差 も認められる. $\delta_{1}, \delta_{2}$ の推定値が負であることは, 生 産責任制の導入と交易条件の改善は, 技術非効率の縮 小, 言い換えれば, 生産効率の改善に貢献しているこ とを意味する. 両者の推定值によれば，1980～84年間 の生産責任制の普及は耕種農業の発展に大きく貢献 し, 年 $4.2 \%$ の成長率をもたらしたこと, また全分析 期間を通じて交易条件の 1 ポイントの上下変動があれ

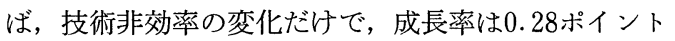

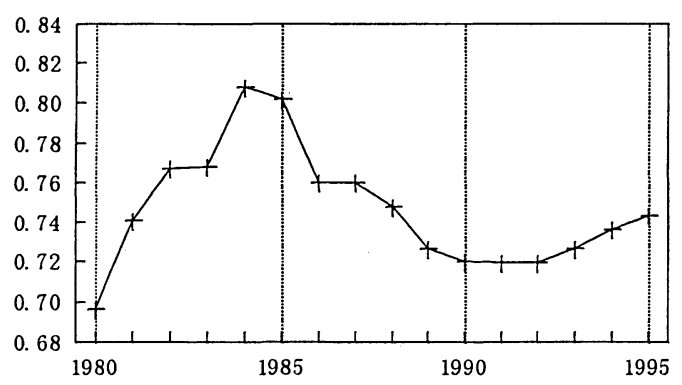

図 1. 耕種農業の平均生産効率の推移（1980～95年） 資料 : 筆者作成.
上下していたと見ることができる.

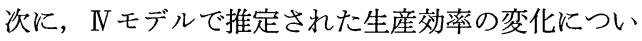
てみよう. 図 1 は1980年以降に郝ける対象28省市自治 区の平均生産効率の推移を表している，それによる と, 耕種農業の生産効率は, 80 年代前半まで急ピッチ で改善されたが，後半以降急降下し，1990～92年間の 停滞期を経て，近年ようやく上向きになった．生産効 率の変化の原因について，次節でみる.

\section{5. 農業成長の要因分析}

さて，以上の生産関数の推定結果を基に，本節では 耕種農業の成長会計分析を行う．そのため，まず（5） 式を（4）式に代入し，時間に対して偏微分すると, 次式が得られる.

$$
\begin{gathered}
\mathrm{G}(\mathrm{Y})=\mathrm{b}_{1} \mathrm{G}(\mathrm{S})+\mathrm{b}_{3} \mathrm{G}(\mathrm{K})+\mathrm{b}_{4} \mathrm{G}(\mathrm{F})+\mathrm{b}_{5} \Delta \mathrm{FE} \\
+\mathrm{b}_{6} \Delta \mathrm{NDP}-\delta_{1} \Delta \mathrm{HRS}-\delta_{2} \Delta \mathrm{AIP}+\Delta \mathrm{A}
\end{gathered}
$$

ただし， $\mathrm{G}(\cdot)$ は変化率， $\Delta$ は変化を表し， $\Delta \mathrm{A}$ $\left(\mathrm{A}_{\mathrm{it}}=\mathrm{b}_{0}+\nu_{\mathrm{it}}-\delta_{0}-\mathrm{w}_{\mathrm{it}}\right)$ は残差項である.

いま, $\mathrm{G}(\mathrm{Y}), \mathrm{G}(\mathrm{S}), \mathrm{G}(\mathrm{K}), \mathrm{G}(\mathrm{F}), \Delta \mathrm{FE}, \Delta \mathrm{NDP}$, $\Delta \mathrm{HRS}, \Delta \mathrm{AIP}$ は観測データより計算でき，また $\mathrm{b}_{1}, \mathrm{~b}_{3}$, $\mathrm{b}_{4}, \mathrm{~b}_{5}, \mathrm{~b}_{6}, \delta_{1}, \delta_{2}$ は表 3 の推定結果を使光ば, 全国耕種 農業の平均成長率 $G(Y)$ 飞対する各説明変数の寄与 を計算できる. 表 4 は三つの時期に分けて年平均成長 率とそれに対する諸要因の寄与をまとめている.

それによると，第 I 期（1980～84年）には耕種業生 産額の成長率が $9.9 \%$ と最も高い，その成長率の中， 通常生産要素投入の増加は5.2ポイント, 被災率の低 下は 0.7 ポイント寄与したが, 生産責任制の導入の寄 与も 4.2 ポイント (41.9\%) 飞達し, 第 I 期の高成長 率を決定づけたと思われる。この時期に，農業財政支 出は縮小され，交易条件も若干悪化したので，この両 政策要素は成長率に負の影響を及ぼした．同じ時期の 中国農業成長の要因を分析した林毅夫氏（1994）もほ ぼ同じような結論を出している．彼の分析結果によれ ば，1979 84年間に耕種農業成長の $46 \%$ は生産要素の 投入増加，47\%は生産責任制の導入によるという。

第II期（1984～90年）に成長率は大幅に落ち込及， $2.4 \%$ となった．成長率の低下に対して，一部の原因 は要素投入増加の鈍化と被災率の増大にある。しか し, 両者を合わせても成長率を1.3ポイントしかダウ ンさせず，成長率低下の最大の原因はやはり先活どみ た生産効率の低下にあった．生産効率に影響する要因 として, 生産組織改革と交易条件変化の二つが挙げら れる. 両者の成長率への奇与をみると，第 I 期に前者 は4.2ポイント，後者はー0.4ポイントであったが，今 
表 4 . 時期別耕種農業成長の要因分析

\begin{tabular}{|c|c|c|c|c|c|c|c|c|c|}
\hline \multirow{2}{*}{ 変数項目 } & \multirow{2}{*}{ 推定係数 } & \multicolumn{4}{|c|}{ 要 因 変 化 } & \multicolumn{4}{|c|}{ 要 因 寄 与 } \\
\hline & & 第 I 期 & 第II期 & 第而期 & 全期間 & 第 I 期 & 第期 & 第正期 & 全期間 \\
\hline A. 生産額 & & & & & & $\begin{array}{c}9.938 \\
(100.0)\end{array}$ & $\begin{array}{c}2.389 \\
(100.0)\end{array}$ & $\begin{array}{r}3.895 \\
(100.0)\end{array}$ & $\begin{array}{r}4.859 \\
(100.0)\end{array}$ \\
\hline B. 通常投入 & & & & & & $\begin{array}{l}5.218 \\
(52.5)\end{array}$ & $\begin{array}{r}4.765 \\
(199.5)\end{array}$ & $\begin{array}{c}4.294 \\
(110.2)\end{array}$ & $\begin{array}{l}4.727 \\
(97.3)\end{array}$ \\
\hline 土地 & 0.404 & -0.370 & 0.474 & 0.203 & 0.158 & -0.150 & 0.191 & 0.082 & 0.064 \\
\hline 労働 & 0.000 & 0.136 & -0.550 & -2.896 & -1.179 & 0.000 & 0.000 & 0.000 & 0.000 \\
\hline 機械・役畜 & 0.187 & 7.057 & 6.190 & 4.491 & 5.850 & 1.320 & 1.158 & 0.840 & 1.094 \\
\hline 化肥 & 0.498 & 8.128 & 6.861 & 6.773 & 7.168 & 4.048 & 3.417 & 3.373 & 3.570 \\
\hline C. 被災率 & -0.632 & -1.168 & 0.238 & 2.002 & 0.451 & $\begin{array}{c}0.737 \\
7.4)\end{array}$ & $\begin{array}{l}-0.151 \\
(-6.3)\end{array}$ & $\begin{array}{l}-1.264 \\
(-32.5)\end{array}$ & $\begin{array}{l}-0.285 \\
(-5.9)\end{array}$ \\
\hline D. 財政支出 & 0.084 & -2.118 & 4.221 & 7.115 & 3.495 & $\begin{array}{l}-0.177 \\
(-1.8)\end{array}$ & $\begin{array}{l}0.353 \\
(14.8)\end{array}$ & $\begin{array}{l}0.595 \\
(15.3)\end{array}$ & $\left.\begin{array}{c}0.293 \\
6.0\end{array}\right)$ \\
\hline E. 組織改革 & 4.165 & 1.000 & & & 0.267 & $\begin{array}{l}4.165 \\
(41.9)\end{array}$ & & & $\begin{array}{l}1.111 \\
(22.9)\end{array}$ \\
\hline F. 交易条件 & 0.282 & -1.485 & -5.547 & 0.810 & -2.345 & $\begin{array}{l}-0.418 \\
(-4.2)\end{array}$ & $\begin{array}{c}-1.563 \\
(-65.4)\end{array}$ & $\begin{array}{c}0.228 \\
\left(\begin{array}{c}5.8 \\
)\end{array}\right.\end{array}$ & $\begin{array}{l}-0.661 \\
(-13.6)\end{array}$ \\
\hline G. 残差 & & & & & & $\left.\begin{array}{c}0.413 \\
4.2\end{array}\right)$ & $\begin{array}{l}-1.016 \\
(-42.5)\end{array}$ & $\left.\begin{array}{c}0.042 \\
1.1\end{array}\right)$ & $\begin{array}{l}-0.325 \\
(-6.7)\end{array}$ \\
\hline
\end{tabular}

資料：筆者作成.

註 : 1) 第 I 期は1980 84年，第期は1984～90年，第盀期は1990 95年である.

2）表中データは平均年率，年差であり，（）内の数字は寄与率である.

期になると，それぞれゼロポイント， -1.6 ポイント 飞低下した．両者の寄与の純減が成長率を5.4ポイン ト低下させた計算になる。

第而期（1990～95年）になると，成長率は若干回復 し， $3.9 \%$ となった。前期から今期にかけて, 通常生 産要素と被災率の寄与はむしろ減少し続けている，成 長率の回復に対して, 農業財政支出の拡大は若干貢献 したが，より大きな影響力を与党たのは生産効率と関 連する交易条件と残差項の寄与の変化である. 特に交 易条件が好転したため, 同要素の寄与は前期の -1.6

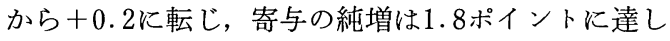
た.

以上，時期ごとに農業成長の原因についてみたが， 3 つの時期を通してみると, 耕種農業成長への最大の 貢献要因は生産要素の投入増加であることは明らかで ある. その寄与は, 時期を追って若干減少したもの の，コンスタントに農業成長に貢献してきた. 生産要 素のうち, 最も貢献したのは化学肥料と機械・役畜で ある. 化学肥料の貢献は全生産要素の寄与の 7 割以 上，機械・役畜のそれも 2 割前後を占めた. それに比 べて, 土地, 労働の影響は非常に小さかった. 一方, 被㷋率の变化は80年代前半に農業成長に正の影響を与 えたが, 後半以降は負となり, 特に90年代に入ってか らは成長率を 1.3 ポイント下げるほど負の影響を及ぼ した.

しかしながら，農業成長率はそれ以上に大きく変動
した. 成長率の変動に対して, 決定的な影響力を持っ たのはほかなら奴生産責任制，農業財政支出と交易条 件などの政策的な要因であった．残差項の変化も基本 的には政策的な環境変化によるものと見られるた め ${ }^{24)}$, 残差項を含めたこれらの政策的な要因の寄与の 合計をみると， 3 つの時期順に $4.0 \rightarrow-2.2 \rightarrow 0.9$ 変 化し, これと平行して成長率は $9.9 \rightarrow 2.4 \rightarrow 3.9$ と変 動してきたのである.

\section{6. むすび}

以上のように，80年代以降急激な制度改革と環境変 化のなか，中国の耕種農業は紆余曲折しながら，全体 的に成長してきた.

本稿の分析によると，対象期間中に中立的な技術進 歩は顕著に現れなかった。耕種農業の成長に最も貢献 したのは化学肥料, 機械といった近代的な生産要素の 投入增加であり，成長率の波動を左右したのは生産責 任制，農業財政支出と交易条件などの政策条件飞影響 された生産効率の変化であった。時期別にみると， 80 年代前半には成長率が9.9\%に達した，その成長率に 対して, 生産要素の投入增加は5.2ポイント，天候の 恵みは 0.7 ポイント寄与したが，生産責任制の導入も 4.2ポイント貢献し, 同時期の高成長率を決定つけた と思われる. 80 年代後半以降, 成長率は急速に低下し た，それについて，原因の一部は生産要素投入増加の 鈍化と被災率の増大にあるが，大部分は生産責任制の 
増産効果の消失と交易条件の悪化などに起因した生産 効率の低下にあった。 そして，90年代に入ってから， 要素投入と被災率の寄与は引き続き減少したものの， 交易条件の改善と政府の一連の農業振興政策により, 生産効率が好転し, 成長率も若干回復した.

今後, 農業生産を振興するためには, 要素投入の拡 大も必要であるが，より重点的に推進すべきことは効 率改善と技術進歩であると思われる．本稿の分析から 明らかなよらに，農業生産の効率（技術進歩も基本的 に同じとみられる）は農家のインセンティブ，そのイ ンセンティブはまた交易条件などに影響されているた め，効率改善を図るには，まず交易条件を適切な水準 まで改善していかなければならない。しかし小農経済 において，交易条件を改善し，農家のインセンティブ を高めるだけでは限界がある。技術普及，農作業の受 委託と農産物, 生産資材の購売など農家の生産経営を 支援する社会的なサービス組織の育成・強化こそ，こ れから中国政府が真剣に取り込むべき，もう一つの重 要な政策課題と言えよう.

注 1) 国家統計局『中国農村統計年鑑』（1996年版）による と，中国耕種農業の実質成長率は1978～84年間は7.1 \%であったが，1984〜90年間は $2.4 \% ， 1990 ９ 5$ 年間 は3.9\%に低下した。

2）例えば，文献 [5]，〔10]，〔11〕，〔13〕などである. これらは研究方法の差により相違はあるが, 生産責任 制の導入が 80 年代前半の農業成長に大きく貢献したこ とに関しては共通している.

3）生産責任制には内容的な変化もあった．最初は人民公 社の組織体制のまま, 生産隊の統一経営・統一分配下 に生産過程だけを農家に委譲する「定額包工」,「聯産 到組」「聯産到戸」など，まさに生産責任だけ農家に 請け負わせるものが多かったが，次第に土地経営の全 過程を委譲する「包産到戸」「包干到戸」のような「経 営責任制」に変身した. 各種形態の割合の変化は文献 〔7〕の p.160を参照.

4）平均買付価格ではなく, 超過買付価格の対農用資材価 格の比を交易条件としたのは, 両価格が併存する時, 農家経営決定の基準価格が後者だとみられるからであ る. 詳しくは文献 [8]を参照.

5）農村工業化の農業成長への影響について，拙稿〔16] を参照.

6）国家統計局『中国統計年鑑』（統計出版社）1993年版, p.390 による.

7）ある1200戸農家に関する固定調査によると，農家の機 械耕耘作業の外部委託率は1980年に69\%，84年に66 $\%, 87$ 年に $44 \%, 90$ 年に $77 \%$ と変化し，4 時点で機械 灌溉, 病虫害防除の外部委託率もそれぞれ $64 \% \rightarrow 56 \%$ $\rightarrow 53 \% \rightarrow 70 \%, 68 \% \rightarrow 38 \% \rightarrow 35 \% \rightarrow 85 \%$ のよに推移 した（文献〔7]p.50を参照）.

8）1985〜95年間，政府がとった主な農業振興政策を挙げ ると，次のようなるのがある．1986年：地方経済振興 を図るための「星火計画」, 1987年：農業技術普及に よる「農業豊作計画」，1989年：「農業発展基金を設 立，農業資金投入を増やすことに関する国務院通知」, 1990年：「農業技術成果普及活動を促進する政令」, 1991年：「農業社会サービスシステムを建設すること に関する国務院通知」, 1993年：「農業法」と「農業 技術普及法」.

9）それぞれ方法の概要，特徵などに関して，文献〔12〕 がサーベイしている.

10）本モデルは，非効率の大きさを計測するのみならず, その影響要因についても回帰分析できる点で, 従来の 確率フロンティア法と異なる.なお，本モデルは費用 関数にも適用できる. 同モデルとその推定法に関し て, 詳しくは文献 [2]，〔3].〔4]を参照.

11）実質総生産額である．ただし，1993年以降公表された 耕種農業総生産額の統計データには家内手工業と野外 採集業の生産額を含むが，ここではそれらを除去し た.

12）文献 [3]を参照. なお，（3）式の計算はプログラム 化されており，手計算の必要はない。

13）厳密に投入時間など実際投入量変数を使用すべきであ るが, 統計データが得られないので, 就業労働力数で 代替した. 耕種農業の就業労働力数は, 以下のように 見積もった. (1)1980〜85年の間の農林牧副漁労働力数 には生産大隊以下の工業労働者数を含むが，生産大隊 以下の企業に颃いて, 労働者数が総生産額と同速度で 変化することを仮定して, 工業労働者数を除去する. (2)農林牧副漁労働力数から, 生産額構成比に基づき, 耕種農業の就業労㗢者数を計算した。

14）役畜 1 頭 $=0.7$ 馬力で換算した。この換算率は文献 〔11〕による。

15）化学肥料の有効成分施用量である.

16）農業生産支援支出，農業事業費之農業インフラ整備費 を含む. 1980～93年間に 3 者の比率はそれぞれ $39 \%$ ， 37\%，24\%であった.

17）総作付面積のうち，自然災害を受けて平年作より $30 \%$ 以上減産した面積の比率である.

18） P.A. ヨドポロスら（1984）によれば，生産効率とは 価格効率と技術効率との合成概念である．価格効率は 要素の限界代替率がその相対価格に一致する度合いで 測られ，与えられた価格体系に対する生産者の行動, 或いは合理的な企業活動を貫徹する能力に左右され る. 一方, 技術効率は生産要素の性能に対する利用効 率で測り, 与件または外部環境（例えば, 要素の賦存 状況, 市場の構造と競争性, 外部組織など）と, 生産 組織の構造と環境への適応能力や生産者のインセンテ ィブなどによって決められる，その意味で，農業の技 術普及と他の社会サービスの提供も生産効率に影響す るものと考えられる. 残念ながら，これらの变数に関 して正確な統計データは得られない. 
19）直接生産組織のみを指す，その変化は生産責任制の普 及率でとら觉る方法もある（例觉ば，文献〔11]）。乙 かし, 生産責任制の普及は面的な広がりと内容的な変 化の両側面を持つ（詰 3 ）. 統計データ上の普及率は 後に定着化した「包産到戸」「包干到戸」という二つ の形態の生産責任制の普及率であって, 他の形態の普 及率や全体に打ける構成比など, 生産責任制の内容的 な変化をとらえていない。よって，ここでは生産責任 制が普及しつつあった1980〜84年間だけ遁増する変則 的なトレンド変数で農業生産組織の变化を表す。

20）諸変数のデータは，前掲『中国農業年鑑』，『中国農村 統計年鑑』の各年版と『1949 95中国㷋情報告』（統 計出版社）による.

21）詳しくは文献 [2]，〔4]を参照. な拉，同ソフトは インタネット上公開されている.

22）平均生産関数のモデル I KTの推定係数 $\mathrm{b}_{7}$ は $10 \%$ の 水準で有意性が認められたが，T変数は農業財政支出 (FE) と強い相関関係にあり, 前者をモデルに入れる と, 後者の推定係数が有意でなくなる. 背景不明のT より, 内容が明白の FE を選ぶべきである.なお，分 析期間中に確かに耐肥性の強い作物品種が多く使われ るようになったが, 本文の推定結果によれば, このよ らな優良品種の導入は化学肥料投入の增加に伴ら限界 生産性の低下を防ぐのに効果があるにしてる, 限界生 産性を向上させる効力はなかったと見られる。

23) $\ln \mathrm{Y}$ と $\ln \mathrm{L}$ との単純相関係数も-0.09と負である. な拉, 説明变数が就業労働者数であるので, ここでの 推定結果から労動の生産弾力性がゼ口と断論するのが 早計である。

24）推測の域を出ないが，例えば，モデルに説明変数とし て導入できなかった技術普及等援農サービスの提供で ある. 理論的に外部組織による援農サービス提供は農 業生産効率を影響すると考兄られ（註18），現にその 動きもタイミング的に残差項と一致している.

\section{参考文献}

[1] Aigner, D.J., C.A.K. Lovell and P. Schmidt. "Formulation and Estimation of Stochastic Frontier Production Function Models." Journal of Econometrics, Vol. 6 (1977), pp.21-37.

[2] Battese, G.E. and T.J. Coelli. "A Stochastic Frontier Production Function Incorporating a Model for Technical Inefficiency Effects." Working Papers in Econometrics and Applied Statistics, (No.70), Department of Econometrics, Univ. of New England, Australia, (1993).

[ 3 ] Battese, G.E. and T.J. Coelli. "A Model for Technical Inefficiency Effects in a Stochastic Frontier Production Function for Panel Data." Empirical Economics, Vol. 20 (1995), pp.325-332.

[4] Coelli, T.J. A Guide to FRONTIER Version 4.1: A Computer Program for Stochastic Frontier Production and Cost Function Estimation. (CEPA Working Paper,
Univ. of New England, Australia), 1996.

[5] Fan, S. "Effects of Technological Change and Institutional Reform on Production Growth in Chinese Agriculture." American Journal of Agricultural Economy, Vol.73 (1991), pp.266-275.

〔6]胡柏「日本農業の全要素生産性変動の性格と要 因」,『農林業問題研究』第 31 巻第 3 号 (1995), pp.11 -19 .

[7] 郭書田編『变革中的中国農村与農業一中国農村経済改 革実証研究』, 中国財政経済出版社, 1993, pp.158161.

〔8] Joseph C.H. Chai「中国の農業発展」, エドワード K.Y. チェン，丸屋豊二郎編『中国の改革・開放の 10 年と経済発展』, アジア経済研究所, 1992, pp.1-30.

[9] Kalirajan, K.P. and J.C. Flinn. "The Measurement of Farm Specific Technical Efficiency.” Pakistan Journal of Applied Economics Vol.II No.2 (1983), pp.167180.

〔10] Kalirajan, K.P., M.B. Obwona and S. Zhao. “A Decomposition of Total Factor Productivity Growth: Chinese Agricultural Growth Before and After reforms." American Journal of Agricultural Economy, Vol.78 (1996), pp.331-338.

〔11〕林毅夫著『制度, 技術与中国農業発展』, 上海三聯書 店, $1994, \mathrm{pp} .76-106$.

〔12〕 Lovell, C.A.K. and P. Schmidt. "A Comparison of Alternative Approaches to the Measurement of Productive Efficiency." Application of modern Production Theory: Efficiency and Productivity, ed. Ali Dorgramaci and Rolf Fare. Boston: Kluwer Academic Publishers, (1988), pp.3-27.

〔13〕 McMillan, J., J. Whalley and L. Zhu. "The Impact of China's Economic Reforms on Agricultural Productivity Growth." Journal of Political Economy, vol.97 (1989), pp.781-807.

[14] Pitt, M.M. and L.F. Lee. "The Measurement and Sources of Technical Inefficiency in the Indonesian". Journal of Development Economics, 9 (1981), pp.43 -64 .

〔15〕 P.A. ヨドポロス, J.B. ヌジェント著『経済発展理論 一実証的研究一』(鳥居泰彦訳)，慶応通信，1984.

〔16〕沈 金虎「江蘇省の農業成長と農村工業化の影響一蘇 南, 蘇北の計量分析」,『農業経済論集』第 48 巻第 2 号 (1997), pp.25-36.

\section{〈付記〉}

本稿の完成にあたり, 京都大学農学研究科加賀爪優 教授, 九州大学農学部胡柏助教授和よびレフェリーか ら貴重なご意見とコメントを頂き，記して感謝の意を 表したい.

(筆者 : 京都大学) 